Original Research Article

\title{
Effect of calcium channel blocker as anticonvulsant and its potentiating effect when used along with sodium valproate in pentylenetetrazole induced seizures in Albino rats
}

\author{
Roopa B. ${ }^{1 *}$, Janardhan M. $^{2}$, Karunasree $\mathbf{P}^{3}$
}

${ }^{1}$ Department of Pharmacology, RVM Institute of medical sciences and research centre. Laxmakkapally, Mugulu, Medak, Telangana, India ${ }^{2}$ Department of Pharmacology, RIMS, Adilabad, Telangana, India

${ }^{3}$ Department of Pharmacology, ESIC Medical College, Sanathnagar, Hyderabad, Telangana, India

Received: 20 January 2018 Accepted: 05 March 2018

\section{*Correspondence to: \\ Dr. Roopa B., \\ Email: roopa_3008 \\ @ rediffmail.com}

Copyright: (C) the author(s), publisher and licensee Medip Academy. This is an openaccess article distributed under the terms of the Creative Commons Attribution NonCommercial License, which permits unrestricted noncommercial use, distribution, and reproduction in any medium, provided the original work is properly cited.

\begin{abstract}
Background: Many antiepileptic drugs were introduced for the treatment of epilepsy. Ideal antiepileptic drug should not only prevent but also correct the underlying pathophysiology without altering the normal neurotransmission. Calcium channel blockers may form such group because initiation of seizure is associated intrinsic burst firing which is triggered by large inward calcium current, so this study was done to evaluate the anticonvulsant effect of amlodipine in albino rats.
\end{abstract}

Methods: A total of 42 adult albino rats were included in the study and divided into 7 groups, each containing 6 rats. Group 1 received distilled water, group 2,3 received sodium valproate $50 \mathrm{mg} / \mathrm{kg}$ and $100 \mathrm{mg} / \mathrm{kg}$, group 4-6 received amlodipine $1,2,4 \mathrm{mg} / \mathrm{kg}$ and group 7 received combination of Amlodipine 1 $\mathrm{mg} / \mathrm{kg}$ and sodium valproate $50 \mathrm{mg} / \mathrm{kg}$. Pentylenetetrazole induced seizures model was done and onset of myoclonic jerks, onset of clonic convulsions and duration of clonic convulsions was studied.

Results: There was a significant anticonvulsant effect in Amlodipine doses 2, $4 \mathrm{mg} / \mathrm{kg}$ ( $\mathrm{p}<0.001)$. The combination of Amlodipine $(1 \mathrm{mg} / \mathrm{kg}$ ) and Sodium valproate $(50 \mathrm{mg} / \mathrm{kg})$ also had significant anticonvulsant effect.

Conclusions: Amlodipine, a calcium channel blocker has anticonvulsant effect and also potentiated the anticonvulsant effect of low dose sodium valproate.

Keywords: Amlodipine, PTZ, Sodium valproate

\section{INTRODUCTION}

Epilepsy is chronic neurological disease and antiepileptic drugs (AEDs) are used for treating epilepsy. An ideal antiepileptic drug should not only abolish the seizure but also correct the pathophysiology of the epileptogenesis without interfering with the normal neural transmission. ${ }^{1}$ The current pharmacological treatment remains insufficient to prevent epileptic seizure. Neither effective prophylaxis nor total cure is available with the available drugs making treatment only symptomatic. Newer drugs introduced had fewer side effects compared to conventional AEDs but they failed to provide complete cure as monotherapy and are used as add on drugs. A new set of drugs with antiepileptic activity without sedation property is an interesting aspect. Calcium channel blockers (CCBs) may have a crucial role in treatment of epilepsy. The initiation of epileptogenic activity in the neuron involves the phenomenon known as "intrinsic burst firing" activated by the inward $\mathrm{Ca}^{2+}$ current. ${ }^{2} \mathrm{Ca}^{2+}$ is the primary 
mediator of excitotoxic neuronal damage during the seizure activity. ${ }^{3} \mathrm{~A}$ fall in the extracellular calcium concentrations occurs prior to onset of seizure activity followed by an increase in the intracellular calcium concentrations. ${ }^{4}$ Amlodipine belongs to the 1,4dihydropyridine (DHP) group of CCBs. Amlodipine exhibits unique features that afford a smooth gradual onset of action and sustained effect that provides for continuous and consistent activity throughout a 24-hour period. It does not alter the plasma concentration of concurrently used other antiepileptics. ${ }^{5,6}$ The present study was planned to evaluate the anticonvulsant activity in PTZ model in albino rats.

\section{METHODS}

\section{Pentyleneterazole (PTZ) induced convulsions model}

The study was done in research laboratory in department of Pharmacology, Kamineni Institute of Medical Sciences, Narketpally, Nalgonda, Telangana for a period of 3 months from January to March 2015. Adult healthy wistar albino rats of either sex, weighing 150-200gm were used in this experiment. Selection was done randomly from the total rats available in the central animal house, KIMS, Narketpally. Selection was done using random number table. Amlodipine, sodium valproate, pentylenetetrazole, distilled water were used in this model. Seven groups of rats were taken for this model, each group were included 6 rats. Three groups of rats were administered with amlodipine in 3 graded doses $(1,2,4 \mathrm{mg} / \mathrm{kg})$. The other groups were administered distilled water (control) and two groups received sodium valproate $(50$ and $100 \mathrm{mg} / \mathrm{kg}$ ) and combination group received amlodipine $1 \mathrm{mg} / \mathrm{kg}$ plus sodium valproate $50 \mathrm{mg} / \mathrm{kg}$ (Table 1 ).

Table 1: Grouping of animals for PTZ model.

\begin{tabular}{|llll|}
\hline $\begin{array}{l}\text { Groups } \\
\mathbf{n}=\mathbf{6}\end{array}$ & Drugs & $\begin{array}{l}\text { Dose } \\
(\mathbf{m g} / \\
\mathrm{Kg})\end{array}$ & $\begin{array}{l}\text { Route of } \\
\text { Administr- } \\
\text { ation }\end{array}$ \\
\hline I & $\begin{array}{l}\text { Distilled water } \\
\text { (control) }\end{array}$ & $5 \mathrm{ml} / \mathrm{kg}$ & Oral \\
\hline II & Sodium valproate & 50 & Ip \\
\hline III & Sodium valproate & 100 & Ip \\
\hline IV & Amlodipine & 1 & Oral \\
\hline V & Amlodipine & 2 & Oral \\
\hline VI & Amlodipine & 4 & Oral \\
\hline VII & $\begin{array}{l}\text { Amlodipine }+ \\
\text { sodium valproate }\end{array}$ & $1+50$ & Oral + ip \\
\hline
\end{tabular}

n-no of rats in each group, ip-intraperitonial

\section{Procedure}

Intraperitoneal injection of pentylenetetrazole (PTZ) at the dose of $80 \mathrm{mg} / \mathrm{kg}$ body weight produced chemically- induced convulsions. The convulsions were clonic in nature and analogous to petit mal (absence) type of seizures. PTZ was administration $30 \mathrm{~min}$ after sodium valproate, one hour after the amlodipine drug administration. In combination group amlodipine was administered one hour before, followed by sodium valproate 30 minutes before the PTZ administration. Each rat was observed for 60 minutes for the development of clonic seizures. The results obtained were noted. The following parameters were observed and recorded were

- Onset time of myoclonic jerks in seconds.

- Onset time of clonic convulsions in seconds.

- Duration of clonic convulsions minutes.

Delay in the onset of myoclonic jerks, clonic convulsions and decrease in the duration of clonic convulsions were considered as anticonvulsant activity.

The data is expressed in mean \pm standard error. Statistical analysis was done using one-way ANOVA and Post-hoc test done by LSD method. SPSS version 19 was employed for statistical analysis.

\section{RESULTS}

Amlodipine in doses of 2 and $4 \mathrm{mg} / \mathrm{kg}$ significantly delayed the onset of myoclonic jerks $(64.17 \pm 2.21$ and $100.83 \pm 2.06$ seconds respectively) in comparison to distilled water (46.83 \pm 3.68 seconds) (Table 2 ).

Combination of amlodipine $1 \mathrm{mg} / \mathrm{kg}$ and sodium valproate $50 \mathrm{mg} / \mathrm{kg}$ significantly delayed the onset of myoclonic jerks $(120.00 \pm 2.22$ seconds) in comparison to their individual drugs (amlodipine $1 \mathrm{mg} / \mathrm{kg} 52.67 \pm 2.37$ seconds and sodium valproate $50 \mathrm{mg} / \mathrm{kg} 51.00 \pm 1.12$ seconds) alone. Amlodipine 2 and $4 \mathrm{mg} / \mathrm{kg}$ significantly delayed the onset of clonic convulsions (121.17 \pm 3.05 and $145.17 \pm 2.29$ seconds) in comparison to distilled water $(88.33 \pm 1.64$ seconds). Combination group significantly delayed the onset of clonic convulsions $(160.00 \pm 3.04$ seconds) in comparison to their individual treatment groups (amlodipine $1 \mathrm{mg} / \mathrm{kg} 94.67 \pm 2.03$ seconds and sodium valproate $100 \mathrm{mg} / \mathrm{kg} 92.83 \pm 2.13$ seconds) alone. Two doses of amlodipine ( 2 and $4 \mathrm{mg} / \mathrm{kg}$ ) significantly decreased the duration of clonic convulsions $(8.17 \pm 0.15$ and $4.82 \pm 0.45$ minutes respectively) in comparison to distilled water (13.34 \pm 0.75 minutes). Combination group significantly decreased the duration of clonic convulsions (2.65 \pm 0.12 minutes) in comparison to their individual drugs (amlodipine $1 \mathrm{mg} / \mathrm{kg} 12.56 \pm 0.23$ minutes and sodium valproate $\quad 50 \mathrm{mg} / \mathrm{kg} \quad 12.52 \pm 0.28 \quad$ minutes) alone. Amlodipine $1 \mathrm{mg} / \mathrm{kg}$ and sodium valproate $50 \mathrm{mg} / \mathrm{kg} \mathrm{did}$ not show any significant effect on onset of myoclonic jerks, onset of clonic convulsions and duration of clonic convulsions. 
Table 2: Effect of drugs in PTZ model.

\begin{tabular}{|lllll|}
\hline Drug & Dose $(\mathrm{mg} / \mathrm{Kg})$ & $\begin{array}{l}\text { Onset of } \\
\text { myoclonic jerks } \\
\text { Mean } \pm \text { SEM (sec) }\end{array}$ & $\begin{array}{l}\text { Onset of clonic } \\
\text { convulsions } \\
\text { Mean } \pm \text { SEM (sec) }\end{array}$ & $\begin{array}{l}\text { Duration of clonic } \\
\text { convulsions } \\
\text { Mean } \pm \text { SEM (min) }\end{array}$ \\
\hline Distilled water (control) & $5 \mathrm{ml} / \mathrm{kg}$ & $46.83 \pm 3.68$ & $88.33 \pm 1.64$ & $13.34 \pm 0.75$ \\
\hline Sodium valproate & 50 & $51.00 \pm 1.12$ & $92.83 \pm 2.13$ & $12.52 \pm 0.28$ \\
\hline Sodium valproate (standard) & 100 & $141.5 \pm 2.62^{* *}$ & $170.83 \pm 1.54^{* *}$ & $2.82 \pm 0.18^{* *}$ \\
\hline Amlodipine & 1 & $52.67 \pm 2.37$ & $94.67 \pm 2.03$ & $12.56 \pm 0.23$ \\
\hline Amlodipine & 2 & $64.17 \pm 2.21^{* *}$ & $121.17 \pm 3.05^{* *}$ & $8.17 \pm 0.15^{* *}$ \\
\hline Amlodipine & 4 & $100.83 \pm 2.06^{* *}$ & $145.17 \pm 2.29^{* *}$ & $4.82 \pm 0.45^{* *}$ \\
\hline Amlodipine + Sodium valproate & $1+50$ & $120.00 \pm 2.22^{* *}$ & $160 \pm 3.04^{* *}$ & $2.26 \pm 0.12^{* *}$ \\
\hline
\end{tabular}

\section{DISCUSSION}

Many studies proved the role of L-type calcium channels in epileptogenesis. Effect of Cinnarazine has been evaluated as a calcium channel blocker on antiepileptic activity of Maximal electroshock seizures(MES) in mice. ${ }^{7}$ Flunarizine $4 \mathrm{mg} / \mathrm{kg}$ was found to have promising effects in both MES and audiogenic seizures. ${ }^{8}$ The present study was done to evaluate the anticonvulsant activity of amlodipine in albino rats in experimental animal model i.e. PTZ model. Amlodipine 2 and $4 \mathrm{mg} / \mathrm{kg}$ and sodium valproate $100 \mathrm{mg} / \mathrm{kg}$ produced significant delay in the onset of myoclonic jerks, clonic convulsions and significant decrease in duration of clonic convulsions in comparison to distilled water.

But the maximal effect observed with amlodipine doses did not exceed the sodium valproate $100 \mathrm{mg} / \mathrm{kg}$ suggesting that sodium valproate $100 \mathrm{mg} / \mathrm{kg}$ is more effective than amlodipine. Low dose of amlodipine $(1 \mathrm{mg} / \mathrm{kg})$ and sodium valproate $(50 \mathrm{mg} / \mathrm{kg})$ alone did not produced compared to control. But their combination i.e. amlodipine $1 \mathrm{mg} / \mathrm{kg}$ and sodium valproate $50 \mathrm{mg} / \mathrm{kg}$ produced significant delay in the onset of myoclonic jerks, clonic convulsions and significant decrease in duration of clonic convulsions indicating potentiating effect of amlodipine when used with sodium valproate.

Kaminski et al, have shown Amlodipine in dose of $10 \mathrm{mg} / \mathrm{kg}$ reduced PTZ-induced clonic and tonic convulsions in mice. It also enhanced the anticonvulsant properties of ethosuccimide, sodium valproate and phenobarbitone without changing their plasma levels. ${ }^{6}$ Satyanarayana et al, also reported decrease in duration of THLE in MES model with amlodipine pretreatment in graded doses $(1 \mathrm{mg} / \mathrm{kg}, 2 \mathrm{mg} / \mathrm{kg}, 4 \mathrm{mg} / \mathrm{kg})$ and also observed delay in the onset of clonic convulsions in PTZ model with similar pretreatments. ${ }^{4}$ Results of present study are comparable to this study. ${ }^{9}$ Jagathi devi et al, showed the combination of amlodipine and indomethacin showed a superior anticonvulsant effect than the use of Amlodipine alone, in both electrically and chemically induced seizures with picrotoxin in mice. ${ }^{2}$
Amlodipine acts as anticonvulsant by blocking $\mathrm{N}$ and $\mathrm{P} / \mathrm{Q}$ type calcium channels along with $\mathrm{L}$ type channels. Blocking of $\mathrm{N}$ type of calcium channels results in inhibition of release of excitatory NT like glutamate responsible for epileptogenesis. ${ }^{10}$ By blocking the L-type calcium channels, the excitation/deplorarization of the neurons is inhibited. ${ }^{11}$ The potentiation effect of amlodipine when used along with the sodium valproate is due to the pharmacodynamic based interaction as both cause calcium channel blocking action and in addition sodium valproate have additional action like modulation of GABA in addition to calcium channel blocking property. Amlodipine potentiates the anticonvulsant action of lamotrigine, gabapentin and topiramate. ${ }^{9}$

\section{CONCLUSION}

The present study showed amlodipine have anticonvulsant effect alone and it has potentiated the effect of sodium valproate in PTZ model in albino rats. However, further clinical studies are still required to establish the role of calcium channel blockers as effective anticonvulsants.

\section{ACKNOWLEDGEMENTS}

Authors would like to thank Dr. Y. Venkata Rao, Dr. C. Dinesh M Naidu for helping me in my work, department of Pharmacology Kamineni Institute of Medical Sciences, Narketpally, Nalgonda District, Telangana and Central animal house, Kamineni Institute of Medical Sciences, Narketpally, Nalgonda District, Telangana for completion of my study.

Funding: No funding sources

Conflict of interest: None declared

Ethical approval: The study was approved by the Institutional Ethics Committee

\section{REFERENCES}

1. Dichter MA, Brodie MJ. New antiepileptic drugs. N Engl J Med. 1996;334:1583-90

2. Jagathi Devi N, Prasanna V. Effect of amlodipine and indomethacin in electrical and picrotoxin induced 
convulsions in mice. Int $\mathbf{J}$ Med Res Health Sci. 2014;3(3):592-6.

3. Kristian T, Siesjo BK. Calcium in ischemic cell death. Stroke. 1998;29:705-18.

4. Beck H, Steffens R, Heinemann U, Elger CE. Ca (2+) -dependent inactivation of high-threshold $\mathrm{Ca}(2+)$ currents in hippocampal granule cells of patients with chronic temporal lobe epilepsy. J Neurophysiol. 1999;82:946-54.

5. Kaminski R, Jasinski M, JagielloWojtowicz E, Kleinrok Z, Czuczwar SJ. Effect of amlodipine upon the protective activity of antiepileptic drugs against maximal electroshock-induced seizures in mice. Pharmacol Res. 1999;40:319-25.

6. Kaminski RM, Mazurek M, Turski WA, Kleinrok Z, Czuczwar SJ. Amlodipine enhances the activity of antiepileptic drugs against pentylenetetrazole induced seizures. Pharmacol Biochem Behav. 2001;68:661-8

7. Brahmane RI, Karpate SV, Shalani Dahat S. John Prem Chandran. Effect of Cinnarazine-As a Calcium Channel Blocker on Antiepileptic activity of Maximal electroshock seizures in mice. Indian $\mathbf{J}$ Pharmacol. 2002;31:280-91.
8. Sahadevan P, Rema MN. A comparative experimental study of the anticonvulsant effect of three calcium channel blockers in albino mice. Indian J Pharmacol. 2002;34:52-5.

9. SathyanarayanaRao KN, Subbalakshmi NK. An experimental study of the anticonvulsant effect of amlodipine in mice. Singapore Med J. 2010;51(5):428.

10. Hassan MAG, Masoud AD. Effect of amlodipine on the antiepileptic action of lamotrigine, gabapentin and topiramate on maximal electroshock induced seizures in mice. Natl J Physiol Pharm Pharmacol. 2014;4(3).

11. Moron MA, Stevens CS, Yaksh TL. The antiseizure activity of dihydropyridine calcium channel antagonists in the conscious rat. Jr Pharmacol Exp Ther. 1990;252:1150.

Cite this article as: Roopa B, Janardhan M,

Karunasree P. Effect of calcium channel blocker as anticonvulsant and its potentiating effect when used along with sodium valproate in pentylenetetrazole induced seizures in albino rats. Int $\mathrm{J}$ Basic Clin Pharmacol 2018;7:714-7. 